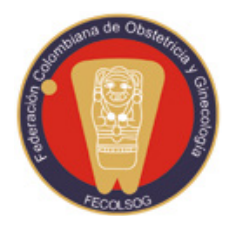

\title{
PLAN FOR ELIMINATING MOTHER-TO-CHILD TRANSMISSION OF SYPHILIS: AN OPPORTUNITY TO START IMPLEMENTING CHANGES TO THE NORMS BASED ON THE HEALTH STATUTORY LAW IN THE COLOMBIAN HEALTH SYSTEM
}

yphilis, a bacterial infection caused by T. pallidum, is a public health problem worldwide. It is estimated that more than 12 million people acquire the infection every year, and Latin America and the Caribbean contribute with 3 million of those cases. (1) In high-income countries, it is considered a re-emergent infection in the 21st century. (2) Syphilis is transmitted through unprotected sexual zintercourse or from the pregnant mother to the foetus through the placenta. Gestational syphilis occurs when an infected woman becomes pregnant or a pregnant woman acquires the infection. (3) Gestational syphilis (GS) may affect the foetus in up to $80 \%$ of cases and lead to miscarriage, foetal demise, preterm delivery, low birth weight, neonatal infection, or congenital syphilis (CS), one of the main causes of perinatal morbidity and mortality. (4)

Syphilis is a curable disease. It is treated with penicillin, (5) and mother-to-child transmission is totally preventable with timely diagnosis and treatment. (6) Good quality antenatal care based on strategies for prompt diagnosis and treatment of the mother may help diminish the incidence of CS. Based on this evidence, the Pan-American Health Organization (PAHO) launched in 1995 the Plan of Action for the Elimination of Congenital Syphilis in Latin America and the Caribbean. The goal of the plan was to lower the incidence of congenital syphilis down to less than 5 cases for every 10,000 live births (LB). (7) Later, in 2007, the World Health Organization (WHO) launched the Global Plan for the Elimination of Congenital Syphilis, (8) and in 2011 Colombia launched the Plan for the Elimination of Maternal Transmission of Syphilis and HIV. (9)

In 2013, the Colombian Ministry of Health and Social Protection reported a prevalence ratio for GS of 6.6/1000 live births and an incidence rate for CS of 17/10,000 live births, (10) three times higher than the goal of the elimination strategy mentioned above.

In an attempt at achieving a greater impact on the incidence of CS, the Ministry of Health and Social Protection and the United Nations Population Fund, under the leadership of the National University, evidence-based Clinical Practice Guideline for the management of GS and CS. The following are the main recommendations included in the Guidelines:

1. Use of treponemal rapid diagnostic tests for pointof-care (POC) use in order to diagnose and treat the pregnant woman in a single visit. These do not require a sophisticated laboratory infrastructure, their sensitivity and specificity are similar to treponemal tests performed in laboratory facilities, (11) are low-cost, (12) and results are available within 30 minutes.

2. Diagnosis of GS is divided into probable (if POC test is positive) and confirmed (when, after a positive POC test, serology is reactive in any dilution).

3. Adequate treatment for the prevention of CS is at least one dose of benzathine penicillin (2.400.000 IU i.m.) given 30 or more days before the time of delivery. Penicillin must be given without prior sensitivity testing at the point of care if the POC test is positive. 
This recommendation is supported on evidence showing that if at least one dose of benzathine penicillin is given 4 weeks before delivery, more than 97\% of cases of neonatal infection may be avoided, and that allergic reactions to penicillin are very rare (3/100,000). (13) Moreover, the risk of treating pregnant women with penicillin for the prevention of CG is very low and does not exceed the benefits of timely treatment for the foetus. In any case, a careful medical interview is required, emphasizing any history of allergic reactions to penicillin or a history of severe hypersensitivity reactions. Patients with any of these antecedents must be referred first for desensitization before receiving the antibiotic.

Adequate implementation of the guideline nationwide is needed in order to use it as a tool to further the goals of the plan for the elimination of mother-to-child syphilis infection. There are existing regulations in the country that need to be considered in devising a plan to improve the elimination strategy. The 2012-2021 Ten-Year Public Health Plan (14) and, more recently, the Health Statutory Law, (15) the Comprehensive Care Policy (16) with emphasis on the comprehensive healthcare model, and the care networks, are a great opportunity to achieve a crossprogramme and inter-sectorial agreement designed to obtain the expected outcomes for the elimination of mother-to-child transmission of syphilis.

It is important to remember that syphilis in Colombia primarily impacts marginal populations affected by great inequities in terms of health, education and opportunities, and who are victims of violence in general and gender violence in particular. On the other hand, the diagnosis and treatment of congenital syphilis does not mobilize the sizable resources that are available for HIV infection. Consequently, there is a need to bring together societal groups that have the resources to act in favour of those with scant possibilities of social mobilization, organization and empowerment. This is even a more pressing need given the country's present circumstances when new opportunities and support for the most vulnerable people is critical if Colombia is to achieve long-lasting peace.
Under the new regulations, it is clear that any effort to eliminate CS must be coordinated by the Ministry of Health. However, territorial agencies of the sector must take the leadership and rally other players in the health system, including insurance companies, service providers and healthcare workers. Other sectors must also be convened, including, but not limited to, the social sector, community organizations, the Colombian Family Welfare Institute (ICBF), academic institutions, scientific societies and the media. The strategy provides an opportunity to again bring primary care to the forefront in the health system, achieve a comprehensive form of antenatal care, organize institutional networks for pregnancy care, and ensure that territorial entities will provide solutions to the problems in the regions, in accordance with their own specific needs. Finally, insurance companies must be required to invest more resources in the prevention of the disease.

The challenge is even greater for scientific societies and the academia. They will need to act on education and training courses offered in medical, nursing and bacteriology schools, as well as on graduate training programmes for clinical specialties in obstetrics, paediatrics, infectious diseases, and dermatology as relates to the content of the guidelines and the new technologies contained in its recommendations, their quality control, and surveillance systems for GS and CS. The role of the scientific societies in continuing education is crucial. It is incumbent upon them to take the leadership in inter-sectorial advocacy for pregnant women in order to ensure their comprehensive care.

The inability to achieve the goals of the strategy would result, in practice, in a new failure of the health system, of the reform, of the Statutory Law, and in a new source of frustration for the Colombian population.

Hernando Gaitán-Duarte, MD, MSc

Editor

\section{Adriana Cruz-Aconcha, MD}

Guest Editor 


\section{REFERENCES}

1. World Health Organization. Global prevalence and incidence of selected curable sexually transmitted diseases: overview and estimates. Geneva: WHO; 2001. (WHO/CDS/CSR/EDC/2001.10). [visited 2016 Mar 20]. Available from: http://www.who.int/hiv/pub/sti/ who_hiv_aids_2001.02.pdf/.

2. Fenton KA, Breban R, Vardavas R, Okano JT, Martin $\mathrm{T}$, et al. Infectious syphilis in high-income settings in the 21 st century. Lancet Infect Dis. 2008;8(4):244-53. doi: 10.1016/S1473-3099(08)70065-3.

3. Kamb ML, Newman LM, Riley PL, Mark J, Hawkes SJ, Malik T, et al. A road map for the global elimination of congenital syphilis. Obstet Gynecol Int. 2010:312798. doi: $10.1155 / 2010 / 312798$

4. Newman L, Kamb M, Hawkes S, Gomez G, Say L, Seuc A, et al. Global Estimates of Syphilis in Pregnancy and Associated Adverse Outcomes: Analysis of Multinational Antenatal Surveillance Data. PLoS Med. 2013;10(2):e1001396. doi: 10.1371/journal. pmed.1001396

5. Workowski KA, Bolan GA, Centers for Disease Control and Prevention. Sexually transmitted diseases treatment guidelines, 2015. MMWR Recomm Rep. 2015;64(RR03):1-137.

6. WHO. Global guidance on criteria and processes for validation: elimination of mother-to-child transmission (EMTCT) of HIV and syphilis. Geneva: WHO; 2014. [visited $2016 \mathrm{Mar} 20]$. Available from: http://apps.who. int/iris/bitstream/10665/112858/1/9789241505888_ eng.pdf?ua $=1$ \&ua $=1$.

7. Plan of action for the elimination of congenital syphilis. Washington, DC: Pan American Health Organization; 1995 (PAHO/WHO/Ce116/14).

8. World Health Organization. The Global elimination of congenital syphilis: rationale and strategy for action. Geneva: WHO; 2007. [visited 2016 Mar 20]. Available from: http://www.who.int/reproductivehealth/ publications/rtis/9789241595858/en/.
9. Plan estratégico para la eliminación de la transmisión materno-infantil del VIH y la sífilis congénita. Colombia 2011-2015. Dirección General de Salud Pública. Ministerio de la Protección Social. Bogotá D.C.;2011.

10. Datos propios de la estrategia para la eliminación de la transmisión materno-infantil del VIH y de la sífilis congénita. Ministerio de Salud y Protección Social; 2015

11. Jafari Y, Peeling RW, Shivkumar S, Claessens C, Joseph L, Pai NP. Are Treponema pallidum specific rapid and point-of-care tests for syphilis accurate enough for screening in resource limited settings? Evidence from a meta-analysis. PLoS One. 2013;8:e54695. doi: 10.1371/journal.pone.0054695.

12. Sweeney S, Mosha JF, Terris-Prestholt F, Sollis KA, Kelly H, Changalucha J, et al. The costs of accessible quality assured syphilis diagnostics: informing quality systems for rapid syphilis tests in a Tanzanian setting. Peeling RW. Health Policy Plan. 2014;29:633-41. doi: 10.1093/heapol/czt049.

13. Galvao TF, Silva MT, Serruya SJ, Newman LM, Klausner JD, Pereira MG, et al. Safety of benzathine penicillin for preventing congenital syphilis: a systematic review. PLoS One. 2013;8:e56463.

14. Ministerio de Salud y Protección Social. Plan Decenal de Salud Pública 2012-2021. [visited 2016 Mar 20]. Available from: https://www.minsalud.gov. co/Documentos\%20y\%20Publicaciones/Plan\%20 Decenal\%20-\%20Documento\%20en\%20consulta\%20 para\%20aprobaci\%C3\%B3n.pdf

15. Ministerio de Salud y Protección Social. Ley Estatutaria 1751 de 2015. [visited 2016 Mar 20]. Available from: https://www.minsalud.gov.co/Normatividad_Nuevo/ Ley\%201751\%20de\%202015.pdf

16. Ministerio de Salud y Protección Social. Resolución 429 de 2016. Política de atención en salud. [visited 2016 Mar 20]. Available from: https://www.minsalud.gov.co/ Paginas/politica-integral-de-atencion-en-salud.aspx 